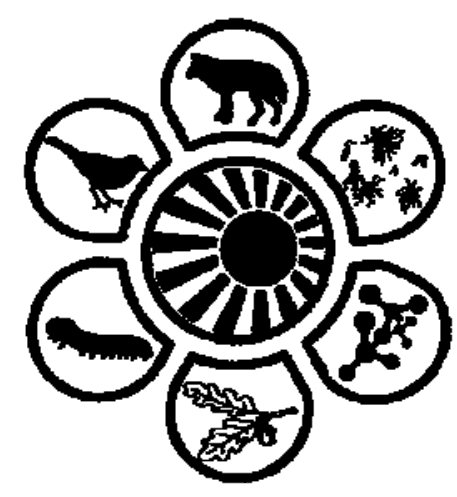

Вісник Дніпропетровського університету. Біологія, екологія.

Vìsnik Dnìpropetrovs'kogo unìversitetu. Seriâ Bìologiâ, ekologiâ

Visnyk of Dnipropetrovsk University. Biology, ecology.

Vìsn. Dnìpropetr. Unìv. Ser. Bìol. Ekol. 2014. 22(2), 122-132.

doi: $10.15421 / 011418$

ISSN 2310-0842 print

ISSN 2312-301X online

www.ecology.dp.ua

\title{
Гістологічна будова травного тракту куликів (Aves, Charadrii)
}

\author{
Л.П. Харченко, І.О. Ликова \\ Харківський національний педагогічний університет імені Г.С. Сковороди, Харків, Украӥна
}

\begin{abstract}
Досліджено гістологічну будову травного тракту 12 видів куликів (Aves, Charadrii). Установлено, що стінка травного тракту куликів на гістологічному рівні складається із трьох оболонок: слизової (епітеліальний шар, власна пластинка слизової оболонки, підслизова основа), м'язової та серозної оболонки. У власній пластинці слизової оболонки стравоходу куликів виявлено велику кількість езофагальних залоз, які виділяють слиз і сприяють просуванню корму уздовж стравоходу. У залозистому шлунку куликів розташовані глибокі складні залози, парієтально-пептичні клітини, які продукують одночасно пепсиноген і соляну кислоту. Установлено адаптації травного тракту куликів на гістологічному рівні до далеких міграцій, пов'язані з будовою стінки кишечника: складне просторове розташування пластинок слизової оболонки та утворення лабіринтів і анастомозів, багатошарове розташування крипт у стінці тонкого кишечника та високий рівень проліферації камбіальних клітин, що забезпечує регенерацію ентероцитів. Усі вищезазначені особливості гістологічної будови стінки травної трубки сприяють інтенсифікації процесів травлення на міграційних зупинках і дозволяють куликам засвоїти за короткий термін велику кількість доступних кормів.
\end{abstract}

Ключові слова: далекі мігранти; міграційні зупинки; стравохід; шлунок; кишечник

\section{Histological structure of the digestive tract of waders (Aves, Charadrii)}

\author{
L.P. Kharchenko, I.A. Lykova \\ G.S. Scovoroda Kharkiv National Pedagogical University, Kharkiv, Ukraine
}

Histological structure of digestive tracts of 12 species of waders (Aves, Charadrii) has been studied: Pluvialis squatarola (Linnaeus, 1758), Charadrius hiaticula (Linnaeus, 1758), Recurvirostra avosetta (Linnaeus, 1758), Tringa ochropus (Linnaeus, 1758), T. glareola (Linnaeus, 1758), T. nebularia (Gunnerus, 1767), T. erythropus (Pallas, 1764), Philomachus pugnax (Linnaeus, 1758), Calidris minuta (Leisler, 1812), C. ferruginea (Pontoppidan, 1763), C. alpina (Linnaeus, 1758) and Gallinago gallinago (Linnaeus, 1758). The features of histological structure of all parts of the digestive tract of the waders species under analysis were defined and adaptations in the structure of the digestive system to distant migrations were detected. It is determined that the histological structure of the wall of the esophagus of the studied species of waders is universal, and the relief of mucosa is folded; stratified squamous epithelium of the mucous membrane has an insignificant degree of hornification. A large number of esophagus glands is observed in the lamina propria of the mucosa; these glands secrete mucus which facilitates the movement of food along the esophagus. The muscular coat is well-developed and formed by longitudinal and circular layers of smooth muscle tissue. It is found that characteristics of histological structure of the stomach wall of the waders species under analysis are presupposed by the following functions: 1) glandular stomach wall provides secretion of digestive enzymes through active secretory activity of glands of deep complex; 2) secretion (mucus) of simple tubular glands is excreted to the surface of glandular stomach performing the protective function; 3 ) the wall of the muscular stomach provides mechanical treatment of food through well-developed muscle layer and solid layer of the cuticle. It is established that the waders' intestine is shortened, that is compensated by the complication of the relief of intestinal mucosa by plates that form complex mazes and anastomoses, several times increasing the absorbing surface of the intestine. The plates are covered with a single layer of prismatic bordered epithelium which includes Goblet cells, the number of which increases in the caudal direction of intestines. It is found out that the particular feature of the histological structure of the examined wall of the waders' small intestine is multi-layer location of crypts in the mucosa. A large number of cambial cells with figures of mitosis were noticed in the crypt, which indicated the intensive processes of proliferation of intestinal enterocytes. These features in the structure of the wall of the small intestine are considered as adaptations to distant migrations and are connected with waders' intense nutrition on migration stops. For the first time Meckel diverticulum has been found in waders and its histological structure has been described. It is established that waders' Meckel diverticulum is a lymphoid-epithelial organ and it serves as the immune system of waders' digestive tract. It is stated that the

Харківський наиіональний педагогічний університет імені Г.С. Сковороди, вул. Артема, 29, Харків, 61002, Украӥна Skovoroda Kharkiv National Pedagogical University, Artema str., 29, Kharkiv, 61002, Ukraine

Tel.: +38-097-079-39-85. E-mail: harchenko.lp@yandex.ua 
wall of waders' rectum has wrinkles that contribute to its stretching; mucous membrane has the plate relief, it is lined with a single layer of epithelium bordered with many Goblet cells. It is revealed that different parts of the investigated waders' cecum have uneven development of histological structures and the presence of lymphoid tissue clusters in the lamina propria mucosa indicates the functional belonging of the cecum to the immune defense system of waders' digestive tract; the presence of mainly bordered enterocytes in the surface epithelium indicates its osmo-regulatory function.

Keywords: long-distance migrants; migration stopover; esophagus; stomach; intestine

\section{Вступ}

Травна система куликів нині залишається практично не дослідженою. Перші фрагментарні дослідження анатомічної будови травної системи куликів зустрічаються в роботах Г. Гадова (Gadov and Selenka, 1891), П. Лове (Lowe, 1931a) і Ф. Гребельса (Groebbels, 1932), але вони мають описовий характер. Анатомічна будова травної системи куликів досліджена та описана Є.В. Козловою (Kozlova, 1961), де також фрагментарно наведено результати гістологічних досліджень будови м'язового шлунка.

Дослідження більшості авторів щодо травної системи куликів як далеких мігрантів стосуються переважно адаптаційних особливостей травної системи у зв'язку $з$ далекими трансатлантичними міграціями (Piersma et al., 1993, 1999; Piersma, 1998; Starck, 1999; Dekinga et al., 2001; Stein et al., 2005). Різка зміна кормів, різних за походженням і калорійністю, характерна для птахів - далеких мігрантів, серед яких особливе місце належить куликам. Травна система забезпечує розщеплення поживних речовин i, таким чином, поповнює енергетичні запаси організму куликів під час міграцій.

Вивчення пластичності травної системи птахів - далеких мігрантів та визначення джерел енергії для їх організму під час далеких перельотів - сучасні тенденції досліджень фізіології мігруючих птахів (McWilliams and Karasov, 2005; Bulakhov and Pakhomov, 2010; MunozGarcia et al., 2011; Bauchinger and McWilliams, 2012). Дослідження будови травної системи мігруючих птахів дозволить зберегти їх на території локальних біотопів, окремих регіональних утворень і держави в цілому (Pakhomov and Brygadyrenko, 2005; Bulakhov et al., 2003, 2008; Pakhomov et al., 2011; Bobyliov et al., 2014).

Основним джерелом енергії для куликів - далеких мігрантів під час перельоту є ліпіди (Guy et al., 2007; Yohannes et al., 2010), які запасаються у передміграційний період або на міграційних зупинках у вигляді абдомінального жиру у черевній порожнині. У разі нестачі жирових запасів під час міграцій як джерело енергії птахи споживають білок, у першу чергу це білок слизових оболонок органів травлення (Bauchinger and McWilliams, 2012). Для інтерпретації механізмів, які лежать в основі зазначених вище фізіологічних процесів, на нашу думку, не достатньо комплексних досліджень, у тому числі гістологічної будови стінки травного тракту птахів - далеких мігрантів. Мета даної статті - з'ясувати будову травної системи куликів - далеких мігрантів на гістологічному рівні та виявити особливості ії̈ будови, пов'язані $з$ далекими міграціями.

\section{Матеріал і методи досліджень}

Матеріал дослідження - травні системи 12 видів куликів. Це сивка морська Pluvialis squatarola (Linnaeus,
1758), пісочник великий Charadrius hiaticula (Linnaeus, 1758), чоботар Recurvirostra avosetta (Linnaeus, 1758), коловодник лісовий Tringa ochropus (Linnaeus, 1758), коловодник болотяний T. glareola (Linnaeus, 1758), коловодник великий T. nebularia (Gunnerus, 1767), коловодник чорний T. erythropus (Pallas, 1764), брижач Philomachus pugnax (Linnaeus, 1758), побережник малий Calidris minuta (Leisler, 1812), побережник червоногрудий C. ferruginea (Pontoppidan, 1763), побережник чорногрудий C. alpina (Linnaeus, 1758), баранець звичайний Gallinago gallinago (Linnaeus, 1758).

Матеріал збирали протягом 2011-2013 рр. у спільних експедиційних виїздах 3 орнітологами Азово-Чорноморської орнітологічної станції до різних біотопів АзовоЧорноморського регіону. Травні системи досліджуваних видів куликів фіксували в 5-6\% водному розчині нейтрального формаліну. Гістологічну будову різних відділів стінки травного тракту досліджували на поперечних i поздовжніх зрізах. Гістологічні препарати виготовляли, використовуючи загальноприйняті методики, викладені у керівництвах із гістологічної техніки (Lilli, 1969; Sarkisov and Petrov, 1986). Морфометрію оболонок стінки травного тракту проводили за допомогою окуляр-мікрометра АМ-9-2. Матеріал для ілюстрацій фотографували під тринокулярним мікроскопом XSP-139TP JNOEC (Японія) із застосуванням цифрової камери DCM300 (USB 2.0).

\section{Результати та їх обговорення}

Стравохід. Результати гістологічних досліджень будови стінки стравоходу 12 видів куликів дозволяють виділити загальні закономірності та особливості гістологічної будови стінки стравоходу даної групи птахів. У досліджених видів куликів слизова оболонка стравоходу утворює добре виражені складки, форма яких різноманітна: у більшості видів складки листкоподібної (Ch. hiaticula, G. gallinago, T. glareola, C. minuta, C. ferruginea, Ph. pugnax) або пальцеподібної (P. squatarola, T. ochropus, T. nebularia) форми, у R. avosetta складки мають витягнену клиноподібну форму. Висота складок варіює від 228 до 1119 мкм. За рахунок розтягування складок відбувається збільшення просвіту стравоходу під час проходження корму.

Слизова оболонка стравоходу досліджених куликів вистелена багатошаровим плоским епітелієм, ступінь зроговіння епітелію незначний, оскільки більшість куликів живляться безхребетними тваринами зі слабко хітинізованими покривами. Товщина епітеліального шару складає 31-93 мкм і має найбільшу товщину у птахів, корм яких складається $з$ великої кількості представників типів членистоногих і молюсків (G. gallinago, T. glareola, T. ochropus, Ch. hiaticula). У брижача, до складу корму якого входять зерна злакових культур, епітеліальний шар стравоходу також має значну товщину. У стравоході брижача виявлено псевдоволо, стінки якого мають 
здатність розтягуватись, збільшуючи просвіт стравоходу у даній ділянці у 5-6 разів. Епітеліальний шар стравоходу куликів, у кормі яких переважають поліхети та хірономуси, розвинений слабко - 31-47 мкм $(R$. avosetta, C. ferruginea, C. alpina, C. ferruginea, T. nebularia).

Власна пластинка слизової оболонки стравоходу в усіх досліджених видів куликів представлена пухкою сполучною та ретикулярною тканинами, де розміщена велика кількість езофагальних залоз. Вивідні протоки езофагальних залоз відкриваються на поверхню епітеліального шару у просвіт стравоходу. Езофагальні залози всіх досліджених куликів вистелені одношаровим призматичним епітелієм і розташовані у власній пластинці слизової оболонки (рис. 1).

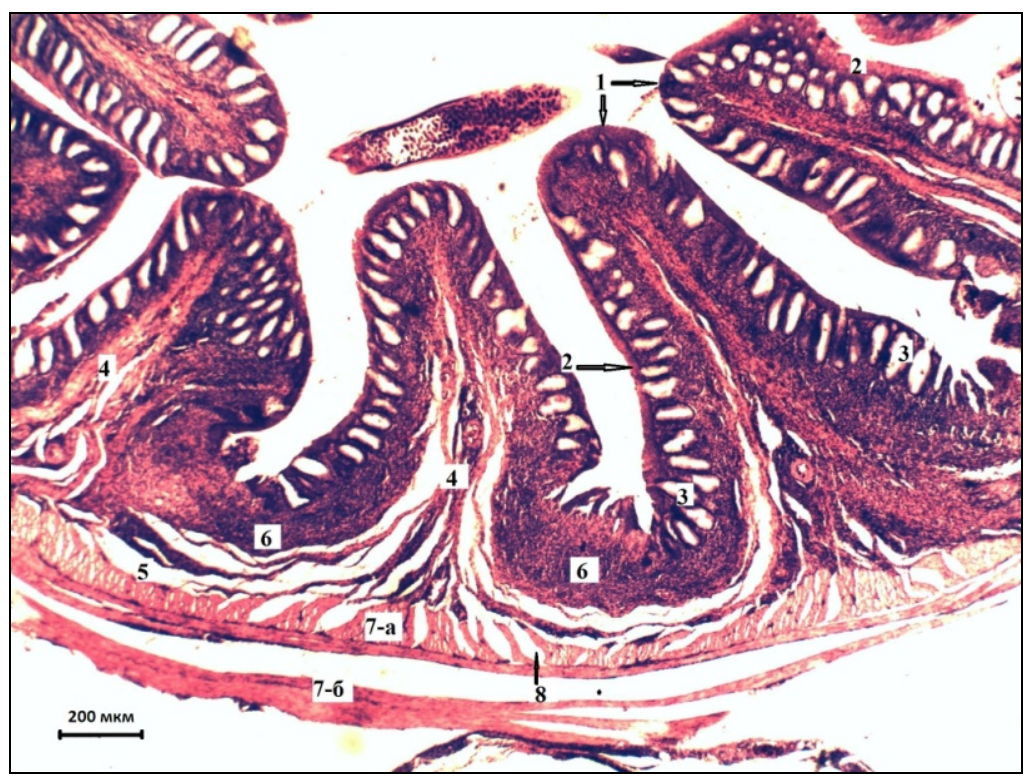

Рис. 1. Стінка стравоходу коловодника великого (Tringa nebularia Gun.), поперечний зріз, каудальний відділ, гістопрепарат (гематоксилін і еозин, ${ }^{\text {40): }}$ 1 - складки, 2 - епітеліальний шар, 3 - езофагальні залози, 4 - м'язова пластинка, 5 - підслизова основа, 6 - дифузно розташовані лімфоцити, 7 - м'язова оболонка (a - внутрішній поздовжній шар, б - зовнішній коловий шар), 8 - прошарки сполучної тканини

Між езофагальними залозами добре розвинена капілярна сітка судин. Навколо залоз розташовані окремі міоцити м'язової пластинки, скорочення яких сприяє виділенню секрету із залоз. У всіх досліджених куликів поблизу залоз розташовуються лімфоїдні структури, представлені лімфоїдними вузликами та дифузно розташованими лімфоцитами, що виконують захисну функцію у передньому відділі травного тракту.

М'язова пластинка слизової оболонки представлена пучками гладкої м'язової тканини, яка під час механічного подразнення кормом скорочується та сприяє розширенню просвіту стравоходу. Товщина м'язової пластинки слизової оболонки складає від 25 до 71 мкм.

Переміщенню корму до шлунка сприяють перистальтичні скорочення м'язової оболонки стравоходу, яка утворена двома шарами гладкої м'язової тканини: поздовжній шар (внутрішній), який забезпечує маятникоподібні рухи, завдяки чому пермішується корм; коловий шар (зовнішній) виконує сфінктероподібні скорочення та переміщення корму. Узгоджені скорочення колового та поздовжнього шарів м'язової оболонки зумовлюють перистальтичні рухи, які сприяють пересуванню корму у каудальному напрямку. Шари м'язової оболонки пронизані прошарками пухкої сполучної тканини, в якій розташовані кровоносні судини та нервові сплетіння та яка сприяє розтягуванню стінки стравоходу. Крім перистальтичних скорочень для м'язової оболонки стравоходу характерні антиперистальтичні скорочення, які забезпечують викидання погадок (представники роду Tringa).
У Ph. pugnax, порівняно з іншими видами досліджених куликів, установлено зміни взаємного розташування шарів м'язової оболонки: внутрішній шар - коловий, зовнішній - поздовжній. На нашу думку, таке розташування шарів м'язової оболонки один відносно іншого можна пояснити наявністю несправжнього вола у брижача та особливостями трофічної спеціалізації (зерна злакових культур). Зерна злакових, що накопичуються у волі, активно змочуються слизом, який виділяють езофагальні залози, а сфінктероподібні скорочення колового шару м'язової оболонки підтримують тонус стінки цієї ділянки стравоходу, утримують корм, який порційно надходить до шлунка.

У всіх досліджених куликів зовнішня серозна оболонка представлена пухкою волокнистою сполучною тканиною 3 поздовжньо-орієнтованими кровоносними судинами та нервовими пучками.

Гістологічна будова стінки стравоходу у досліджених видів куликів універсальна, рельєф слизової оболонки складчастий, багатошаровий епітелій слизової оболонки стравоходу має незначний ступінь зроговіння. У власній пластинці слизової оболонки відмічено велику кількість езофагальних залоз, які виділяють слиз, що сприяє пересуванню корму уздовж стравоходу. Інтенсивному пересуванню корму уздовж стравоходу до залозистого шлунка сприяє добре розвинена м'язова оболонка, утворена поздовжнім і коловим шарами гладкої м'язової тканини.

Шлунок. У зоні переходу стравоходу у залозистий шлунок епітеліальний шар слизової оболонки стає тон- 
ким, багатошаровий епітелій переходить в одношаровий. У слизовій оболонці езофагальні залози зникають і 3'являються глибокі складні залози (рис. 2). У всіх до- сліджених видів куликів слизова оболонка залозистого шлунка утворює численні заглибини - прості трубчасті залози, довжина яких у різних видів складає 37-457 мкм.

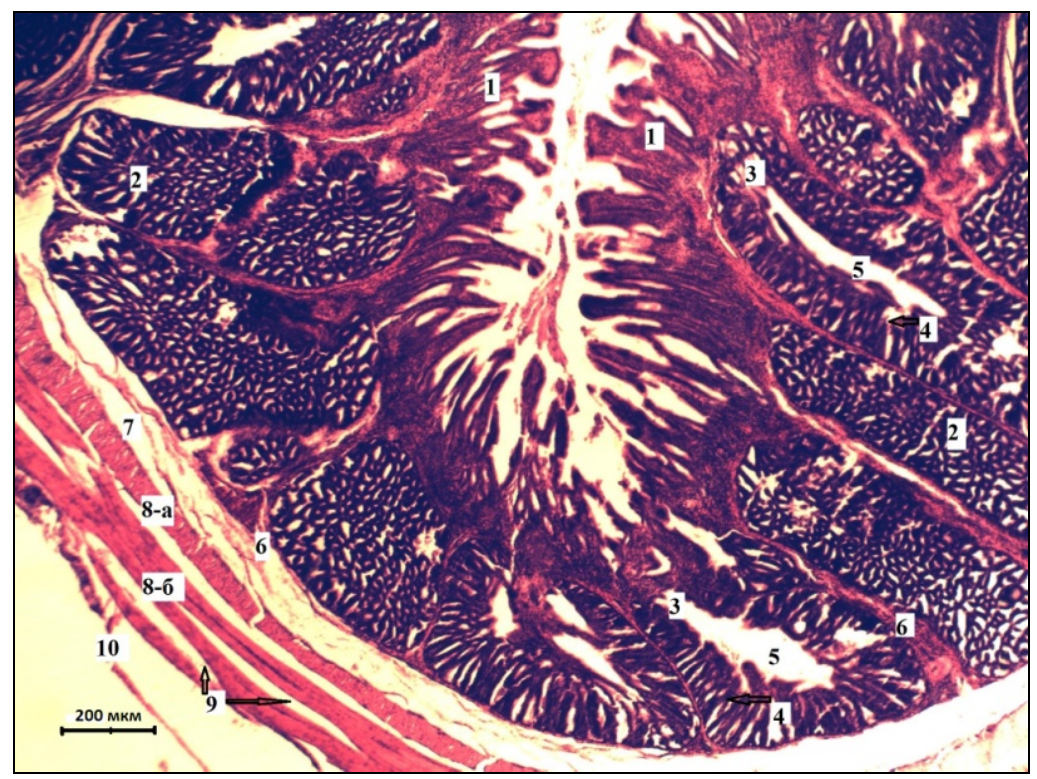

Рис. 2. Стінка залозистого шлунка коловодника великого

(Tringa nebularia Gun.), поперечний зріз, гістопрепарат (гематоксилін і еозин, ${ }^{\text {×40): }}$

1 - трубчасті залози, 2 - глибокі складні залозі, 3 - кінцеві відділи глибоких складних залоз, 4 - вторинні

протоки, 5 - первинна протока, 6 - міоцити м'язової пластинки, 7 - підслизова основа, 8 - м'язова оболонка

(a - внутрішній поздовжній шар, б - зовнішній коловий шар), 9 - прошарки сполучної тканини, 10 - серозна оболонка

Внутрішня поверхня слизової оболонки залозистого шлунка вистелена одношаровим призматичним залозистим епітелієм, який глибоко заходить у складки слизової та вистилає порожнини простих трубчастих залоз (рис. 2). Ядра епітеліоцитів слизової оболонки приплюснуті до базальної мембрани, на апікальному полюсі клітин виділяється секрет, який покриває поверхню залозистого шлунка шаром в'язкого слизу, до складу якого входить велика кількість кислих мукополісахаридів, що мають бактерицидні властивості (Kharchenko, 2005). Між трубчастими залозами розташовані пучки міоцитів, які забезпечують скорочення залоз і виділення у порожнину шлунка секрету.

Власна пластинка слизової оболонки залозистого шлунка представлена пухкою сполучною та ретикулярною тканинами. М'язова пластинка слизової оболонки залозистого шлунка в усіх досліджених куликів представлена окремими міоцитами гладкої м'язової тканини.

Найрозвиненішим шаром слизової оболонки залозистого шлунка є підслизова основа, в якій розташовані глибокі складні залози, парієтально-пептичні клітини яких виконують подвійну секреторну функцію, одночасно продукуючи пепсиноген i соляну кислоту. Глибокі складні залози розташовуються в один шар і мають видовжену (T. glareola, $T$. ochropus, $T$. nebularia, C. ferruginea, G. gallinago, Ch. hiaticula) або округлу (P. squatarola $T$. erythropus, R. avosetta) форму; або у декілька шарів і мають переважно багатокутну форму (C. alpina, C. minuta, Ph. pugnax). У всіх досліджених куликів складні глибокі залози компактно згруповані, міжзалозиста сполучна тканина майже не розвинена.

Складні глибокі залози формуються із залозистих дольок, які не розгалужені, оскільки вони у великій кількості не накопичують пепсин, а він постійно виділяється під час подразнення їжею слизової оболонки. Кожна залозиста долька складається 3 великої кількості альвеол, утворених одношаровим залозистим епітелієм стовпчастої та кубічної форми. Апікальні частини клітин не прилягають щільно одна до одної, між клітинами залишаються щілиноподібні проміжки. Ця особливість будови гландулоцитів пов'язана 3 тим, що ці клітини виконують функцію подвійної секреції, поєднуючи в собі секрецію пепсиногену та соляної кислоти (Batoev and Naletova, 2008). Між парієтально-пептичними клітинами у птахів $€$ міжклітинні канальці, які дають шестиразове збільшення вільної клітинної поверхні та прискорюють виділення компонентів шлункового соку.

Пепсин, який виділяють парієтально-пептичні клітини, виводиться через третинні протоки залози в порожнини залозистих дольок. Порожнини залозистих дольок об'єднуються у вторинні вивідні протоки, які, у свою чергу, відкриваються у центральну первинну протоку, через яку пепсин виводиться на поверхню залозистого шлунка. Дольки складних залоз оточені з усіх боків сполучною тканиною, яка містить колагенові та еластичні волокна, а також пучки міоцитів, що заходять із м'язової пластинки слизової оболонки, скорочення яких сприяє виділенню пепсину (рис. 2).

М'язова оболонка залозистого шлунка в усіх видів досліджених куликів двошарова, але має різне взаємне розташування шарів один відносно іншого. У більшості досліджених видів внутрішній шар утворений поздовжньо орієнтованими пучками міоцитів, а зовнішній - коловими, в інших - навпаки (C. ferruginea, C. minuta, Ph. pugnax). Між шарами м'язової оболонки розташовані прошарки сполучної тканини. 
Серозна оболонка залозистого шлунка складається 3 пухкої волокнистої сполучної тканини, вкритої простим плоским епітелієм - мезотелієм. У серозній оболонці виявлено численні кровоносні судини.

М'язовий шлунок куликів, як і інших птахів, представлений порожнистим органом, у якому створюються оптимальні умови для механічної та хімічної обробки корму. Будова стінки м'язового шлунка досліджених птахів характеризується формуванням щільної кутикули. Під шаром кутикули утворюються невеликі заглиблення шлункові ямки, у дно яких відкриваються протоки простих трубчастих залоз, де їх секрет змішується із секретом шлункових ямок, який виділяють поверхневі епітеліоцити, твердіє та формує стовпчики кутикули (рис. 3).

Слизова оболонка м'язового шлунка досліджених птахів вистелена одношаровим призматичним залозистим епітелієм, впинання якого у власну пластинку слизової оболонки утворюють прості нерозгалужені трубча- сті залози, розташовані щільно та паралельно одна одній, пронизуючи майже всю товщу власної пластинки слизової оболонки. Тіло та шийка залоз вистелені одношаровим кубічним епітелієм, ядра епітеліоцитів щільно прилягають до базальної мембрани, мають оксифільну цитоплазму. Середня товщина слизової оболонки разом із залозами складає 257-694 мкм.

У досліджених куликів кутикула щільно прилягає до слизової оболонки, повторюючи ії рельєф, має жовтозелене забарвлення. Забарвлення кутикули залежить від двох пігментів, що входять до складу жовчі: білірубіну та білівердіну (Naletova, 2009). Під час зворотньої перистальтики пігменти разом із жовчю потрапляють у шлунок. У всіх досліджених видів куликів кутикула однорідна, середня іï товщина мінлива - від 57 до 412 мкм. Найміцніша та найтовща кутикула у G. gallinago (412 мкм) і Ph. pugnax (503 мкм), що, напевно, пов'язано з великою часткою твердих кормів, які споживають ці види куликів.

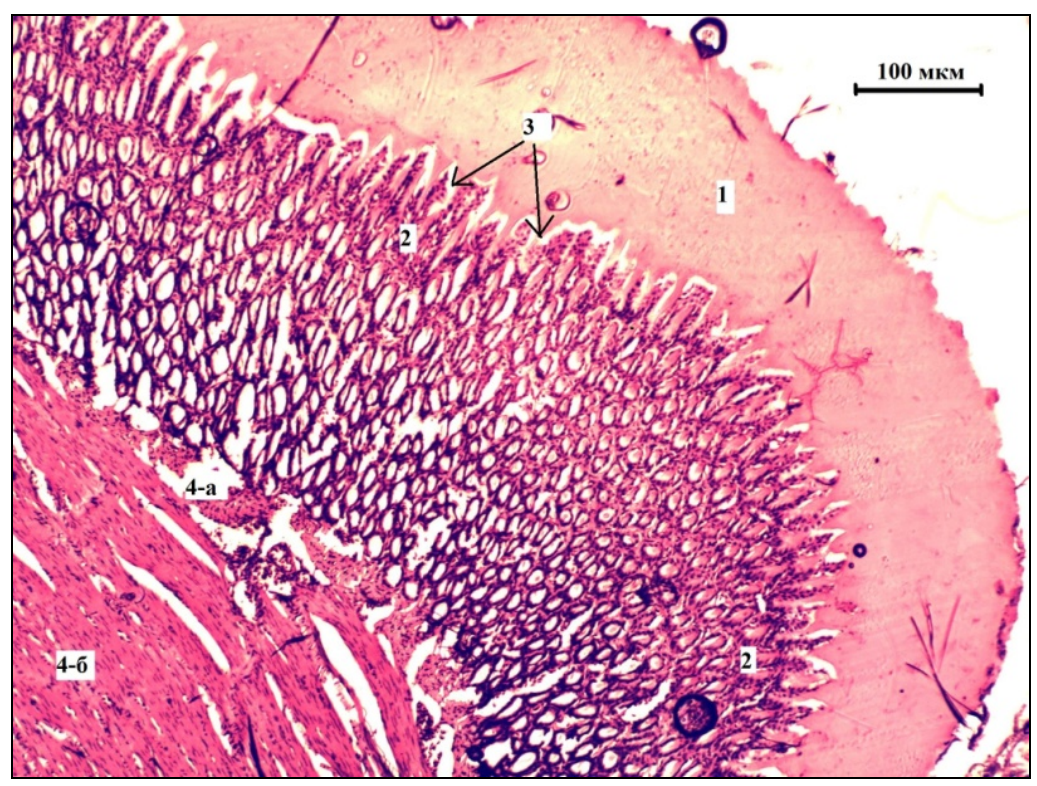

Рис. 3. Стінка м'язового шлунка коловодника болотяного (Tringa glareola L.), поперечний зріз, гістопрепарат (гематоксилін і еозин, ${ }^{\mathbf{1 0 0}}$ ):

1 - кутикула, 2 - трубчасті залози, 3 - шлункові ямки, 4 - м'язова оболонка ( $а$ - внутрішній поздовжній шар, б - зовнішній коловий шар)

У всіх досліджених видів куликів м'язова оболонка м'язового шлунка товста, що разом із кутикулою сприяє механічній обробці корму. М'язова оболонка складається із пучків міоцитів, у саркоплазмі яких міститься велика кількість міоглобіну, що й зумовлює іiї темний колір. М'язова оболонка м'язового шлунка двошарова, внутрішній шар тонкий (78-158 мкм), складається 3 поздовжньо-орієнтованих пучків міоцитів, а зовнішній (коловий) - товстий (305-5 385 мкм). Між пучками міоцитів м'язової оболонки містяться прошарки пухкої сполучної тканини 3 кровоносними судинами. Коловий шар на дорсальному та вентральному боках шлунка утворює два головні трикутні м'язи, які починаються від сухожильного центра - сухожильного дзеркальця, утвореного численними пучками колагенових волокон. Між головними бічними м'язами лежать проміжні м'язи, які формують стінки сліпих мішків.

Серозна оболонка м'язового шлунка представлена пухкою сполучною тканиною, вкритою мезотелієм.
Таким чином, особливості гістологічної будови стінки шлунка досліджених видів куликів зумовлені ії функціональними властивостями: 1) стінка залозистого шлунка забезпечує виділення травних ферментів шляхом активної секреторної активності глибоких складних залоз; 2) секрет (слиз) простих трубчастих залоз виділяється на поверхню залозистого шлунка та виконує захисну функцію; 3) стінка м'язового шлунка забезпечує механічну обробку корму за рахунок добре розвиненої м'язової оболонки та міцного шару кутикули.

Тонкий кишечник досліджених куликів, як і інших птахів, представлений дванадцятипалою, порожньою та клубовою кишками. В усіх досліджених видів куликів установлено ускладнення рельєфу слизової оболонки кишечника за рахунок складного просторового розташування пластинок, вкритих одношаровим призматичним облямованим епітелієм. На поверхні плазмолеми облямованих ентероцитів завершуються процеси травлення (пристінне травлення) та відбувається всмоктування 
поживних речовин. В епітеліальному шарі також розміщена велика кількість бокалоподібних клітини, які продукують слиз. Кількість бокалоподібних клітин в епітелії пластинок збільшується в каудальному напрямку.

Особливістю гістологічної будови слизової оболонки дванадцятипалої кишки досліджених куликів $є$ наявність «анастомозів» між кишковими пластинками (рис. 4). У T. erythropus, T. glareola, C. ferruginea, C. alpina плас- тинки зростаються та утворюють практично суцільний шар; у T. nebularia та T. ochropus пластинки утворюють анастомози біля основи; у G. gallinago, Ch. hiaticul, C. minuta, Ph. pugnax, $P$. squatarola кількість анастомозів значно зменшується, рельєф слизової оболонки представлений видовженими пластинками з гладкою поверхнею або розсіченими верхівками. Висота кишкових пластинок варіює від 258 до 685 мкм.

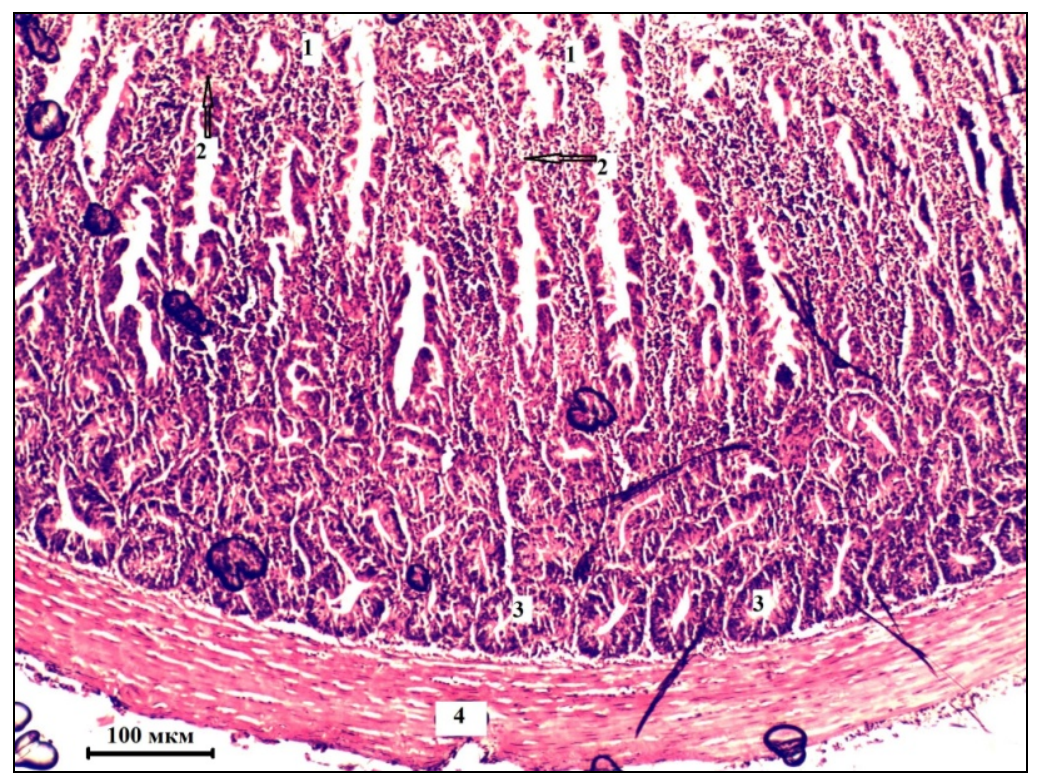

Рис. 4. Стінка дванадцятипалої кишки коловодника болотяного (Tringa glareola L.), поперечний зріз, краніальний відділ, гістопрепарат (гематоксилін і еозин, $\left.{ }^{\mathrm{1}} 100\right)$ :

1 - пластинки слизової оболонки, 2 - анастомози між пластинками, 3 - кишкові крипти, 4 - м'язова оболонка

Покривний епітелій слизової оболонки дванадцятипалої кишки біля основи пластинок утворює інвагінації у власну пластинку слизової оболонки, формуючи кишкові крипти (Ліберкюнові залози). Кишкові крипти досліджених видів куликів мають дно, тіло та перешийок, вистелені циліндричним епітелієм, до складу якого входять облямовані та бокалоподібні ентероцити. Альвеолярне розширення донної частини крипт вказує на їх секреторну функцію. На дні крипт розташовані залозисті клітини Панета, які продукують компоненти кишкового соку, у тому числі пептидази.

За даними Д. Старка (Starck, 1996), проліферація ентероцитів кишечника прискорюється зменшенням інтервалу S-фази, під час якої відбувається реплікація ДНК, тим самим темпи мітотичного поділу камбіальних клітин прискорюються. У досліджених куликів в епітелії крипт виявлено значну кількість фігур мітозів у камбіальних клітинах, що свідчить про високу регенераційну активність ентероцитів (рис. 5). На нашу думку, високий мітотичний індекс камбіальних клітин на дні кишкових крипт свідчить про високу швидкість проліферації ентероцитів. Велика кількість крипт і їх багатошарове розташування у стінці тонкого кишечника досліджених куликів сприяє швидкому оновленню кишкового епітелію, що, у свою чергу, сприяє інтенсифікації процесів травлення та всмоктування поживних речовин під час коротких міграційних зупинок.

У більшості досліджених видів куликів крипти слизової оболонки дванадцятипалої кишки розташовані у 23 шари, мають альвеолоподібно розширену форму (T. ne- bularia, T. erythropus, T. ochropus, T. glareola, C.ferruginea, C. alpina, C. minuta, Ph. pugnax). У P. squatarola i $R$. avosetta крипти розташовані в один шар. Середній діаметр крипт - 20-111 мкм.

М'язова пластинка слизової оболонки дванадцятипалої кишки у досліджених видів куликів представлена окремими міоцитами, які розташовуються між криптами. Підслизова основа слизової оболонки в усіх досліджених видів птахів слабко виражена.

М'язова оболонка стінки дванадцятипалої кишки двошарова, утворена гладкою м'язовою тканиною. Внутрішній шар (поздовжній) - тонкий (11-14 мкм), у деяких видів представлений окремими міоцитами (C. ferruginea, C. alpina, C. minuta), у Ch. hiaticula - розвинений краще (30 мкм). Зовнішній шар (коловий) добре розвинений (78-284 мкм), забезпечує перистальтичні скорочення стінки дванадцятипалої кишки, що сприяє пересуванню хімусу в каудальному напрямку.

Гістологічна будова стінки порожньої та клубової кишок у всіх досліджених видів куликів подібна до гістологічної будови стінки дванадцятипалої кишки. Слизова оболонка вкрита одношаровим залозистим епітелієм, у якому відмічено збільшення кількості бокалоподібних клітин у каудальному напрямку. Рельєф слизової оболонки пластинчастий.

Основні особливості гістологічної будови стінки порожньої та клубової кишок пов'язані зі змінами в архітектоніці слизової оболонки, яка ускладнюється, утворюючи лабіринти та анастомози між пластинками слизової оболонки (рис. 6, 7). У краніальному відділі 
порожньої кишки пластинки слизової оболонки видовжені, тому часто утворюють зигзагоподібні лабіринти, що збільшує загальну площу всисної поверхні. Кількість анастомозів між пластинками порожньої кишки у каудальному напрямку зменшується. Ця тенденція установлена також для клубової кишки.

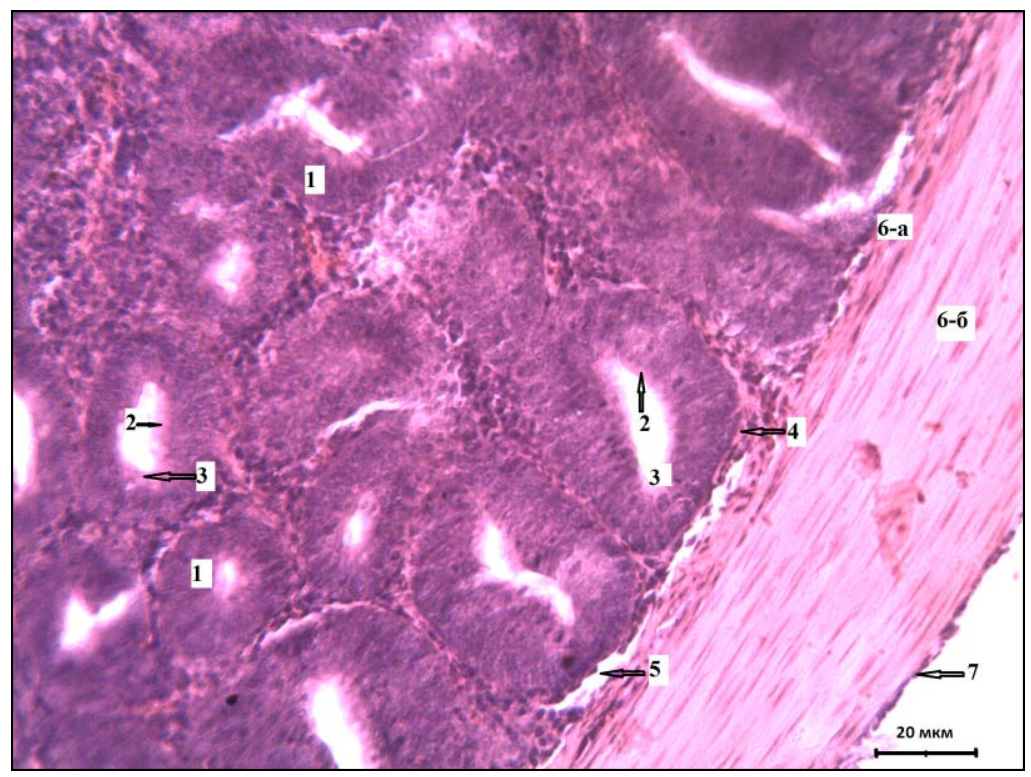

Рис. 5. Крипти у стінці дванадцятипалої кишки коловодника великого (Tringa nebularia Gun.), поперечний зріз,

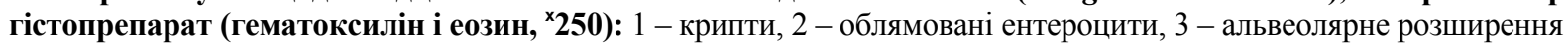
донної частини крипт, 4 - окремі міоцити м'язової пластинки, 5 - підслизова основа, 6 - м'язова оболонка (а - внутрішній поздовжній шар, б - зовнішній коловий), 7 - серозна оболонка

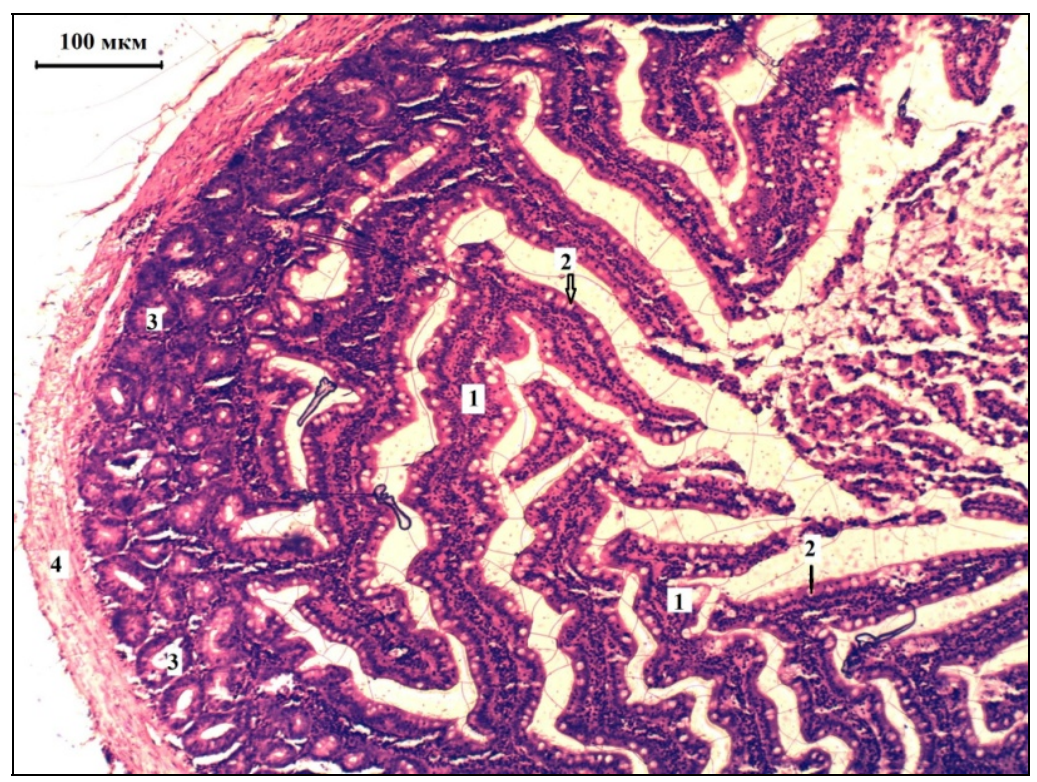

Рис. 6. Стінка порожньої кишки побережника червоногрудого (Calidris ferruginea Pontop.),

поперечний зріз, краніальний відділ, гістопрепарат (гематоксилін і еозин, ${ }^{\text {x } 100):} 1$ - пластинки слизової оболонки, розташовані зигзагоподібно, 2 - бокалоподібні клітини, 3 - кишкові крипти, 4 - м'язова оболонка

Товщина криптального шару порожньої та клубової кишок у каудальному напрямку залишається майже незмінною, а діаметр крипт зменшується (23 -83 мкм), форма їх залишається альвеолоподібною. В епітелії крипт мітотичний індекс епітеліоцитів залишається високим, відмічено збільшення кількості бокалоподібних клітин при проліферації камбіального епітелію крипт. Між криптами розташовані окремі міоцити м'язової пластинки. Наявність крипт і їх висока регенераційна здатність свідчать про інтенсивні процеси травлення та всмоктування поживних речовин уздовж усього тонкого відділу кишеч- ника досліджених куликів, що можна розглядати як адаптацію до інтенсивного живлення на міграційних зупинках.

М'язова пластинка слизової оболонки порожньої та клубової кишок представлена окремими міоцитами; підслизова основа розвинена слабко. М'язова оболонка двошарова: внутрішній шар - поздовжній, тонкий і у більшості досліджених видів представлений окремими міоцитами, зовнішній шар - коловий, добре розвинений. Скорочення міоцитів колового шару стінок порожньої та клубової кишок забезпечують перистальтичні рухи, що сприяє пересуванню хімусу в каудальному напрямку. 
В усіх досліджених видів куликів на антимезентеріальній поверхні каудального відділу порожньої кишки виявлено дивертикул Меккеля, який є справжнім дивертикулом. Слизова оболонка дивертикула Меккеля вкрита одношаровим циліндричним епітелієм, криптальний шар розвинений слабко. У ділянці основи дивертикула Меккеля крипти розташовані в один шар, а в середній ділянці та у верхівці - фрагментарно (рис. 8). Рельєф слизової оболонки в основі дивертикула Меккеля пред- ставлений невисокими пластинками, а в середній ділянці та верхівці слизова оболонка щільно інфільтрована лімфоцитами. М'язова оболонка двошарова: внутрішній шар - поздовжній, тонкий, зовнішній - коловий, добре розвинений. Усі оболонки стінки дивертикула Меккеля інфільтровані лімфоїдними структурами, що дає підстави стверджувати: дивертикул Меккеля у куликів $є$ периферичним органом імунної системи.

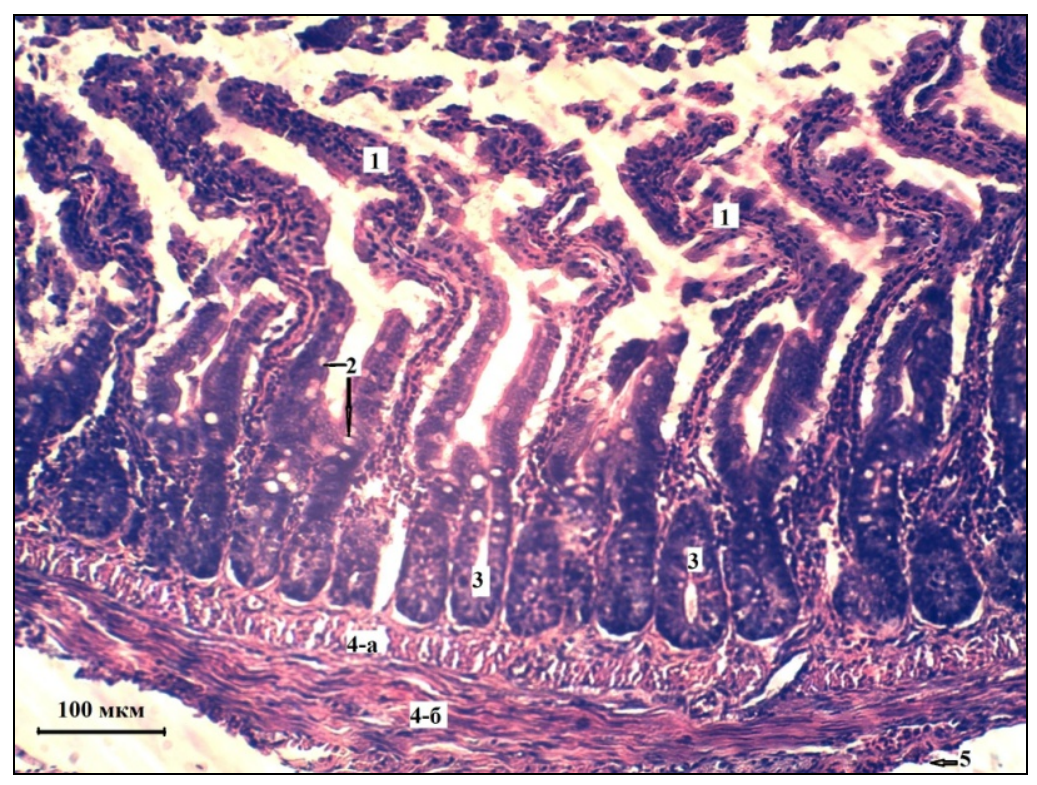

Рис. 7. Стінка клубової кишки пісочника великого (Charadrius hiaticula L.), поперечний зріз, краніальний відділ, гістопрепарат (гематоксилін і еозин, ${ }^{\mathbf{1} 100):} 1$ - пластинки слизової оболонки, 2 - бокалоподібні клітини, 3 - кишкові крипти, 4 - м’язова оболонка (а - внутрішній поздовжній, б - зовнішній коловий шар), 5 - серозна оболонка

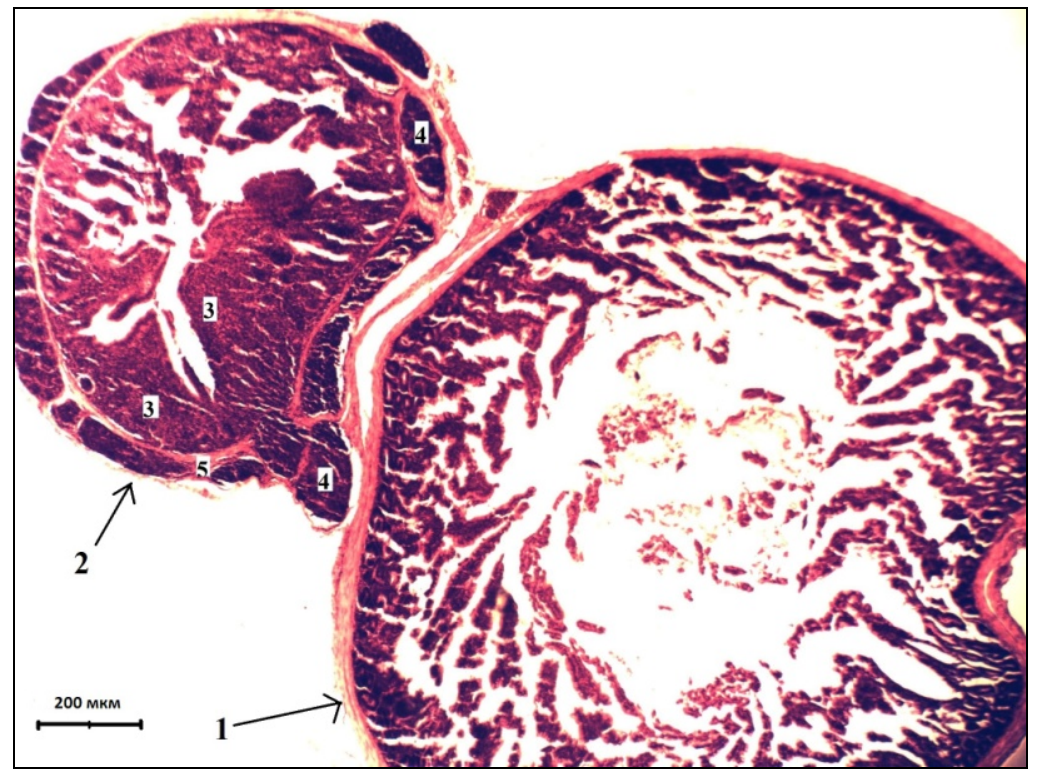

Рис. 8. Дивертикул Меккеля коловодника лісового (Tringa ochropus L.) у середній ділянці, поперечний зріз, гістопрепарат (гематоксилін і еозин, ${ }^{\mathbf{4}} 40$ ):

1 - стінка порожньої кишки, 2 - дивертикул Меккеля, 3 - лімфоїдна тканина, 4 - лімфоїдні бляшки у м'язовій оболонці, 5 - м'язова оболонка

Товстий кишечник у куликів представлений прямою кишкою. Пряма кишка у досліджених куликів складає 3-9\% загальної довжини кишечника та має пластинчастий рельєф. Особливості гістологічної будови стінки прямої кишки пов'язані з ії функціями. У стінці прямої кишки для збільшення поверхні слизової оболонки утворюються складки, в які глибоко заходить м'язова пластинка слизової оболонки та сприяє інтенсивному скороченню складок (рис. 9). Висота складок у досліджених видів куликів варіює від 102 до 600 мкм. 
Рельєф слизової оболонки прямої кишки - пластинчастий. Пластинки слизової оболонки прямої кишки розширюються біля основи. У більшості досліджених видів висота пластинок складає 70-141 мкм. У $R$. avosetta, T. nebularia, T. erythropus, Ph. pugnax пластинки високі (277-372 мкм), іноді утворюють звиви. Щільність розташування пластинок у стінці прямої кишки у переважної більшості досліджених видів зменшується, тому анастомози між пластинками не утворюються.
Слизова оболонка прямої кишки вистелена одношаровим залозистим епітелієм, у якому переважають бокалоподібні клітини. Крипти розташовуються в один шар, мають альвеолоподібну форму, діаметр крипт коливається від 12 до 88 мкм. У криптах відмічено клітини 3 фігурами мітозів, що свідчить про активну секреторну функцію крипт і постійні регенераційні процеси в епітелії прямої кишки.

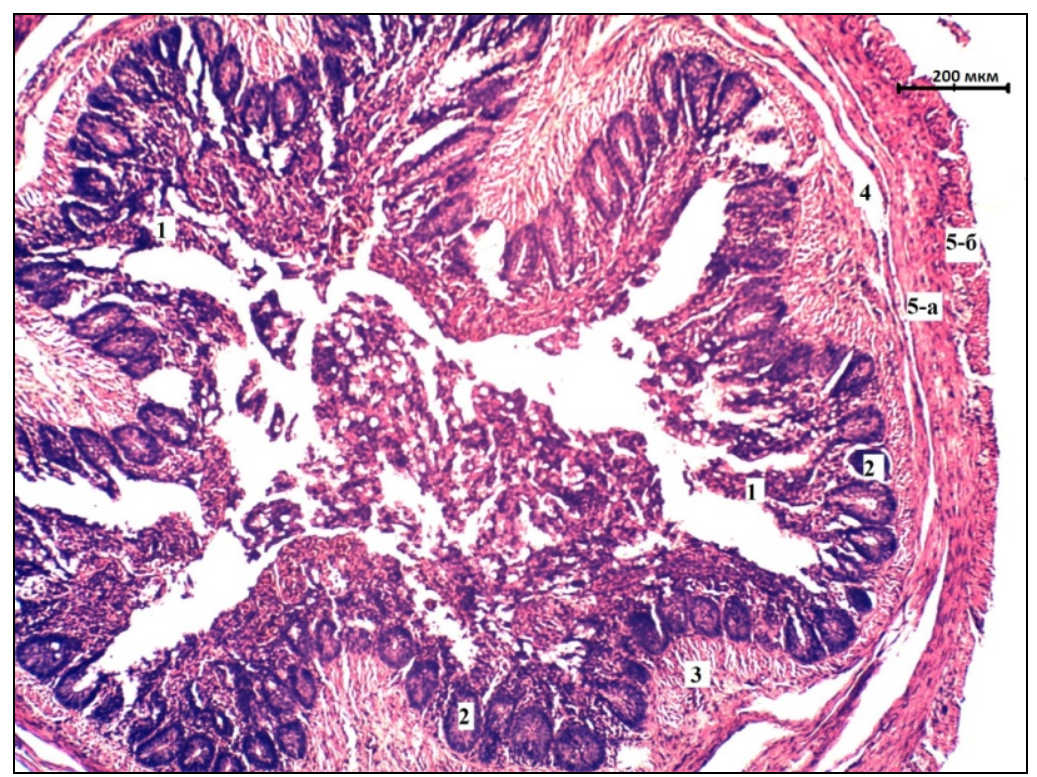

Рис. 9. Складки слизової оболонки прямої кишки пісочника великого (Charadrius hiaticula L.) у каудальному відділі, поперечний зріз, гістопрепарат (гематоксилін і еозин, ${ }^{\text {40): }}$

1 - пластинки, 2 - крипти, 3 - м'язова пластинка, 4 - підслизова основа,

5 - м'язова оболонка (а - внутрішній коловий, б - зовнішній поздовжній шар)

В усіх досліджених куликів у стінці прямої кишки підслизова основа має товщину 10-25 мкм і чітко розділяє м'язову пластинку слизової оболонки та м'язову оболонку, у якій відмічено зміну взаємного розташування шарів м'язової оболонки порівняно 3 тонким кишечником. М'язова оболонка прямої кишки залишається двошаровою: внутрішній шар - коловий, зовнішній - поздовжній. Товщина шарів м'язової оболонки у досліджених куликів різниться. У більшості досліджених видів товщина внутрішнього колового шару коливається в межах 97-271 мкм, зовнішнього поздовжнього - 25-97 мкм. У P. squatarola та C. ferruginea зовнішній поздовжній шар складає 107174 мкм, а товщина колового шару - 40-45 мкм. Взаємне розташування та значна товщина шарів м'язової оболонки та наявність прошарків сполучної тканини сприяють посиленню перистальтичних рухів та прискорюють виведення неперетравлених решток корму.

Зовнішня серозна оболонка представлена пухкою волокнистою сполучною тканиною.

Усі оболонки прямої кишки інтенсивно інфільтровані дифузно розташованими лімфоцитами та вузликами, які виконують захисну функцію.

Сліпі кишки виявлені не в усіх досліджених куликів. У $T$. nebularia та $T$. glareola сліпі кишки редуковані, найбільші їх розміри відмічено у $P h$. pugnax. Морфологічно сліпа кишка поділяється на шийку, основу та верхівку. Слизова оболонка сліпих кишок у всіх досліджених видів куликів вистелена одношаровим об- лямованим епітелієм. Рельєф слизової оболонки в різних ділянках сліпої кишки неоднорідний. У ділянці шийки рельєф слизової оболонки пластинчастий, висота пластинок складає 75-307 мкм. Крипти у власній пластинці слизової оболонки розташовані переважно в один шар, діаметр крипт коливається від 22 до 85 мкм. Власна пластинка слизової оболонки у цій ділянці сліпої кишки інфільтрована лімфоцитами. М'язова пластинка слизової оболонки представлена окремими міцитами, підслизова основа виражена слабко. М'язова оболонка двошарова, внутрішній шар - поздовжній (13-20 мкм), зовнішній коловий (33-164 мкм). У м'язовій оболонці відмічено наявність лімфоїдних вузликів.

У ділянці тіла сліпої кишки у більшості досліджених видів куликів спостерігається нерівномірний розвиток гістологічних структур. У слизовій оболонці дорсомедіальної частини стінки сліпої кишки відмічено концентрацію лімфоїдної тканини (рис. 10). Пластинки слизової оболонки стають менш виражені, розміри крипт і щільність їх розташування зменшуються. У м'язовій оболонці у цій ділянці відмічено лімфоїдні бляшки. У складі поверхневого епітелію відмічено переважно облямовані ентероцити, кількість бокалоподібних клітин значно менша, ніж у прямій кишці. Крипти розташовані в один шар, відмічено наявність у криптах клітин із фігурами мітозів. Підслизова основа у цій ділянці менш виражена, розвиток м'язової оболонки по діаметру сліпої кишки нерівномірний. У ділянці верхівки сліпої кишки в усіх досліджених 
куликів слизова оболонка заповнена лімфоїдною тканиною, крипти відсутні. М'язова оболонка тонка.

Зовнішня серозна оболонка сліпої кишки представлена одношаровим мезотелієм. Нерівномірний розвиток гістологічних структур у різних ділянках сліпої кишки дозволяє стверджувати, що наявність у власній пластин- ці слизової оболонки скупчень лімфоїдної тканини вказує на функціональну приналежність сліпої кишки до системи органів імунного захисту травного тракту куликів, а наявність у складі поверхневого епітелію переважно облямованих ентероцитів свідчить про іiї осморегулювальну функцію.

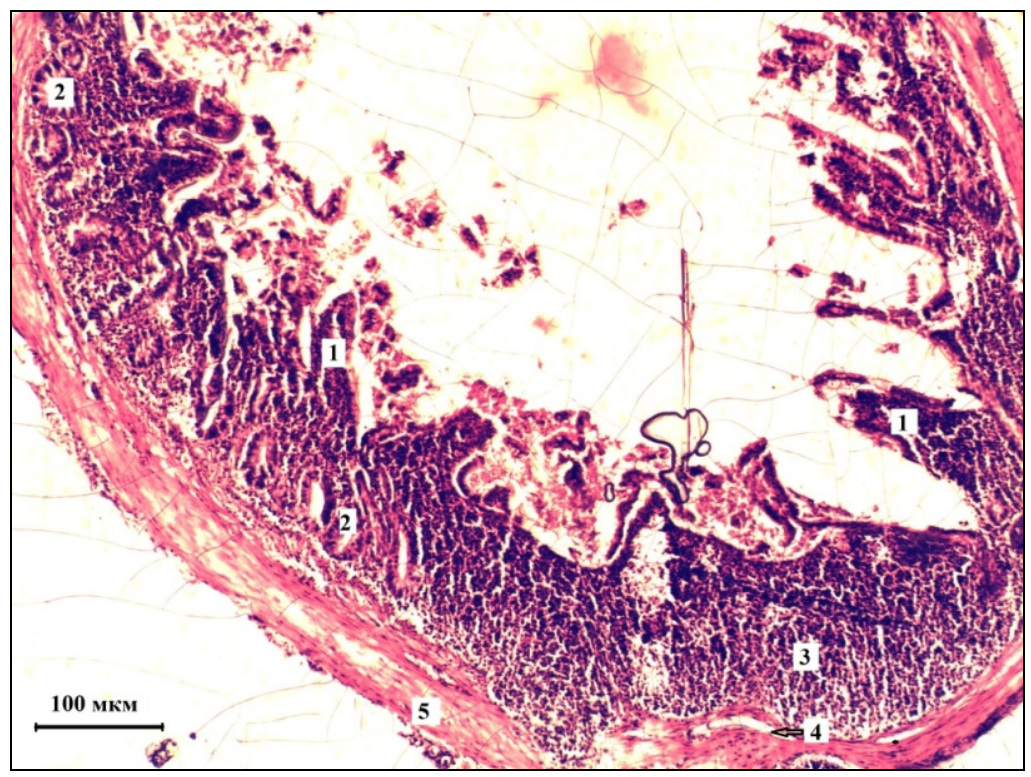

Рис. 10. Стінка сліпої кишки брижача (Philomachus pugnax L.)

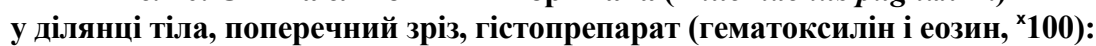

1 - пластинки, 2 - крипти, 3 - лімфоїдна тканина, 4 - підслизова основа, 5 - м'язова оболонка

Таким чином, гістологічні дослідження травного тракту куликів дозволили встановити, що у будові стінки травного тракту сформувалася низка адаптацій, пов'язаних з інтенсифікацією живлення на міграційних зупинках. Нині можна стверджувати, що пластичність травної системи є однією з адаптацій птахів до різкої зміни кормів і до тривалого голодування під час міграцій (McWilliams and Karasov, 2005; Bauchinger and McWilliams, 2012). Зміни гістологічної будови стінки травного тракту сприяють ефективності травлення птахів - мігрантів і визначають межі пластичності їх травної системи.

\section{Висновки}

Травна система куликів виконує одну з основних функцій в організмі птахів на міграційних зупинках: через травний тракт проходить велика кількість кормів, які інтенсивно розщеплюються, поживні речовини всмоктуються у кров, поповнюючи енергетичні запаси організму птахів. Для підтримання такого високого рівня метаболізму у куликів як далеких мігрантів на гістологічному рівні сформувався ряд пристосувань у стінці травної трубки:

- секреторний апарат покривного епітелію (езофагальні залози стравоходу, прості трубчасті залози залозистого шлунка, бокалоподібні ентероцити кишечника), який виконує захисну функцію стінки травної трубки куликів під час інтенсивного живлення на міграційних зупинках;

- просторове розташування пластинок слизової оболонки кишечника, які утворюють складні лабіринти та анастомози, що збільшує поверхню травлення та всмоктування поживних речовин;

- багатошаровість криптального шару у слизовій оболонці тонкого кишечника, що сприяє виділенню великої кількості ферментів у порожнину кишечника, які забезпечують інтенсивний процес травлення та всмоктування поживних речовин на міграційних зупинках;

- високий рівень проліферації в камбіальних клітинах крипт забезпечує постійне оновлення кишкових ентероцитів та прискорює процеси травлення у куликів на міграційних зупинках;

- розвиток шарів м'язової оболонки травної трубки та зміни їх взаємного розташування уздовж травної трубки забезпечують перистальтичні та антиперистальтичні скорочення, що сприяє швидкому проходженню їжі по травному тракту та дає змогу куликам засвоїти максимальну кількість доступних кормів.

\section{Бібліографічні посилання}

Batoev, C.Z., Naletova, L.A., 2008. Zheludochnoe pishhevarenie u ptic [Gastric digestion in birds]. Izd-vo BGU, Ulan-Ude (in Russian).

Bauchinger, U., McWilliams, S.R., 2012. Tissue-specific mass changes during fasting: The protein turnover hypothesis. M.D. McCue (ed.). Comparative physiology of fasting, starvation, and food limitation, 12. Springer-Verlag, Berlin, Heidelberg. pp. 193-206.

Bobyliov, Y.P., Brygadyrenko, V.V., Bulakhov, V.L., Gaichenko, V.A., Gasso, V.Y., Didukh, Y.P., Ivashov, A.V., Kucheriavyi, V.P., Maliovanyi, M.S., Mytsyk, L.P., Pakhomov, O.Y., Tsaryk, I.V., Shabanov, D.A., 2014. Ekologija [Ecology]. Folio, Kharkiv (in Ukrainian). 
Bulakhov, V.L., Emel'janov, I.G., Pakhomov, O.Y., 2003. Bioraznoobrazie kak funkcional'naja osnova jekosistem [Biodiversity as functional basis of ecosystems]. Vìsn. Dnìpropetr. Unìv. Ser. Bìol. Ekol. 11(1), 3-8.

Bulakhov, V.L., Gubkin, A.A., Ponomarenko, O.L., Pakhomov, O.Y., 2008. Biologichne riznomanittya Ukrainy. Dnipropetrovs'ka oblast'. Ptahy: Negorobcepodibni (Aves: NonPasseriformes) [Biological diversity of Ukraine. Dnipropetrovsk region. Aves: Non-Passeriformes]. Dnipropetrovsk Univ. Press, Dnipropetrovsk (in Ukrainian).

Bulakhov, V.L., Pakhomov, O.Y., 2010. Funkcional'na zoologija [Functional zoology]. Dnipropetrovsk Univ. Press, Dnipropetrovsk (in Ukrainian).

Dekinga, A., Dietz, M., Koolhaas, A., Piersma, T., 2001. Time course reversibility of changes in the gizzards of red knots alternately eating hard and soft food. J. Exp. Biol. 204(12), $2167-2173$.

Gadov, H.U., Selenka, E., 1891. Vogel. I Anatomischer Theil. Dr H.G. Bronn's Klassen und Orduungen des Thier-Reichs, 6(4), 1-1008.

Groebbels, F., 1932. Der Vogel. Birds. 1, 32-41.

Guy, M.R.I., Davidson, N.C., Wilson, J.R., 2007. Survival of the fattest: Body stores on migration and survival in red knots Calidris canutus islandica. J. Avian Biol. 38(4), 479-487.

Kharchenko, L.P., 2005. Gistologichna budova zalozystogo shlunku ptahiv riznoi' trofichnoi' specializacii' [Histological structure of the glandular stomach of birds of various food specialization]. Biologija ta Valeologija [Biology and Valueology] 7, 114-123 (in Ukrainian).

Kozlova, E.V., 1961. Rzhankoobraznye. Podotrjad Kuliki [Charadriiformes. Charadrii]. Fauna SSSR. Pticy [Fauna of the USSR. Birds] 2(1), 15-17 (in Russian).

Lilli, R., 1969. Patologicheskaja tehnika i prakticheskaja gistohimija [Pathological technique and practical histochemistry]. Mir, Moscow (in Russian).

Lowe, P.R., 1931. On the relation of the Gruimorphae to the waders Charadriimorphae. Ibis 491-534.

McWilliams, S.R., Karasov, W.H., 2005. Migration takes guts: Digestive physiology of migratory birds and its ecological significance. Birds of Two Worlds 6, 67-78.

Munoz-Garcia, A., Amidor, S., McCue, M.D., McWilliams, S.R., Pinshow, B., 2012. Allocation of endogenous and dietary protein in the reconstitution of the gastrointestinal tract in migratory blackcaps at stopover sites. J. Exp. Biol. 10, 1069-1075.
Naletova, L.A., 2009. Osobennosti kutikuly i kutikuljarnoj plastiny muskul'nogo zheludka kur i gusej [Features of cuticles and cuticular plateof a muscular stomach of hens and geese]. Vestnik Burjatskogo Gosudarstvennogo Universiteta 4, 190-192 (in Russian).

Pakhomov, O.Y., Brygadyrenko, V.V., 2005. Koncepcija systemy zahodiv $\mathrm{z}$ ohorony navkolyshn'ogo pryrodnogo seredovyshha Dnipropetrovs'koi' oblasti na 2005-2015 roky [Concept of system for actions on environment protection in Dnipropetrovsk region for 2005-2015]. Vìsn. Dnìpropetr. Unìv. Ser. Bìol. Ekol. 13(1), 213-225.

Pakhomov, O.Y., Gasso, V.Y., Goloborodko, K.K., Poljakov, M.V., Grycan, Y.I., Bulakhov, V.L., Brygadyrenko, V.V., Kljuchko, Z.F., Mezhzherin, S.V., Novicky, R.O., Pysanec, Y.M., Pljushh, I.G., Ponomarenko, O.L., Puchkov, O.V., Radchenko, V.G., 2011. Chervona knyga Dnipropetrovskoi oblasti. Tvarynnyj svit [The red book of Dnipropetrovsk region. Animals]. New Print, Dnipropetrovsk (in Ukrainian).

Piersma, T., 1998. Guts don't fly: Small digestive organs in obese Bar-tailed Godwits. Auk 115(1), 195-203.

Piersma, T., Dietz, M., Dekinga, A., Nebel, S., van Gils, J., Battley, Ph., Spaans, B., 1999. Reversible size-changes in stomachs of shorebirds: When, to what extent, and why? Acta Ornithol. 34(2), 175-181.

Piersma, T., Koolhaas, A., Dekinga, A., 1993. Interactions between stomach structure and diet choice in shorebirds. Auk 110(3), 552-564.

Sarkisov, D.S., Petrov, J.A., 1986. Mikroskopicheskaja tehnika [The microscopic technique]. Medicina, Moscow (in Russian).

Starck, J.M., 1999. Phenotypic flexibility of the avian gizzard: Rapid, reversible and repeated changes of organ size in response to changes in dietary fibre content. J. Exp. Biol. 202(22), 3171-3179.

Stein, R.W., Place, A.R., Lacourse, T., Guglielmo, C.G., Williams, T.D., 2005. Digestive organ sizes and enzyme activities of refueling Western sandpipers (Calidris mauri): Contrasting effects of season and age. Physiol. Biochem. Zool. 78(3), 434-446.

Yohannes, E., Valcu, M., Lee, R., Kempenaers, B., 2010. Resource use for reproduction depends on spring arrival time and wintering area in an arctic breeding shorebird. J. Avian Biol. 41, 580-590.

Надійшла до редколегії 28.09.2014 